UDC 621.87

\title{
ANALYSIS OF THE START-UP PROCESS OF THE TOWER CRANE SLEWING MECHANISM WITH A STEADY STATE MOTION MODE OF ITS LOAD TROLLEY
}

\author{
V.S. Loveikin ${ }^{1}$, \\ Yu.O. Romasevych ${ }^{1}$, \\ V.P. Kurka ${ }^{1}$, \\ D.I. Mushtyn ${ }^{1}$, \\ K.I. Pochka ${ }^{2}$ \\ ${ }^{1}$ National University of Life and Environmental Sciences of Ukraine \\ ${ }^{2}$ Kyiv National University of Construction and Architecture
}

DOI: $10.32347 / 2410-2547.2020 .105 .232-246$

A mathematical model of the tower crane's slew is developed under the condition of constant velocity of the trolley motion along the boom. The model is derived from the second-order Lagrange equations, calculates the tangential and radial load oscillations on a flexible suspension. An analysis of the system motion with the trolley movement to and from the tower has been conducted. A set of estimated figures has been proposed, which made it possible to establish the level of dynamic and energy load of the crane slewing mechanism, as well as to analyze the evolution of the load oscillations on a flexible suspension.

Keywords: mathematical model, slewing, tower crane, load oscillations, analysis, Lagrange equations.

\section{Introduction}

Tower cranes are widely used in many sectors of the farming industry. They are especially often used in the construction of civil engineering objects. The tower crane slewing mechanism is one of the main. The effective exploitation of this mechanism is related to the dynamic and energy processes that occur in the transient modes of mechanism motion. It is during the starting and braking of the slewing mechanism in the crane elements (shafts, toothed gears, clutches, etc.), the considerable dynamic loads occur. They have a negative impact on the longevity of the mechanism. In addition, one of the important issues for research is the energy efficiency of the crane slewing drive mechanism. These and others factors cause the need to study the dynamic and energy processes in the crane slewing mechanism. Previous studies have found that they have the greatest impact during transient modes of motion.

Moreover, we specify a factor that has a negative impact on the crane performance - the load oscillations on a flexible suspension. In case of crane's slew, the load oscillations occur in the plane of trolley motion and perpendicular to it. In order to develop methods for their elimination, it is necessary to conduct their study and establish the basic laws of their origin and development.

(C) Loveikin V.S., Romasevych Yu.O., Kurka V.P. Mushtyn D.I., Pochka K.I. 


\section{Analysis of publications}

In the paperwork of Vaynson A.A. [1] the calculation of dynamic loads during the operation of the crane slewing mechanism is performed on the basis of a dynamic model with concentrated masses. The integration of the corresponding mathematical model under the condition of starting motion from the quiescent state and with constant driving force allowed to obtain an expression for determining the elastic torque in the crane slewing mechanism. Its analysis allowed the author to make recommendations for reducing dynamic loads in crane elements: it is necessary to increase the inertial features of the drive and to reduce the excess torque (force) of the drive mechanisms. The first method is constructively lies in the insertion of the flywheel to the kinematic chains. This leads to an increase in the start-up time of the mechanisms, which adversely affects its energy indicators. Therefore, the rational way to ensure an acceptable level of dynamic loads at low energy consumption in drive is to control its excessive torque.

In the research of Gaidamaka V.F. [2] the expression of determining the maximum dynamic loads is carried out in the same way: first of all, a dynamic model of the mechanisms is executed, equations of motion of the system reduced masses are recorded, and then the equations are integrated at zero initial conditions and the condition of constancy of the driving factor (torgue or force). The difference in calculations with previous work lies in the moment which is created by the friction forces, the crane tilt and wind. Aside from this, Gaydamaka V.F. did not take into account the effect of centrifugal force in the calculations.

In Scheffler M., Dresig H., Kurt F. [3] the emphasis is on establishing the magnitudes of the deviation of the load from the vertical in radial and tangential directions. This approach is due to the fact that in many calculation methods for the elements of tower cranes it is necessary to know the values of the angles of alteration of the load from the vertical. The authors have shown the results of their own researches and compared them to what is already known.

In general, the approach of determining the dynamic loads at which the driving force is assumed as constant is quite simplistic. It does not reflect the features of the mechanical characteristics of the drive mechanisms, which in many cases are a significant factor in the study of the dynamics of the mechanisms of the crane's slew and changes in load's fly out.

Gohberg M.M. in his work [4] indicated the combinations of load actions that should be used in the calculations of tower crane mechanisms: self-weight, load weight with gripping unit, inertial loads, tilt forces, forces caused by wind loads, as well as mounting and transport loads. The author points out that in the case of low angular velocity of crane's slew, it is permissible to use expressions related to the dynamics of two-mass systems described in $[5,6]$. In this case, the excess effort must be replaced at the appropriate time divided by the magnitude of load's fly out.

One of the important factors that determine the dynamic loads in tower crane elements is the load oscillation on a flexible suspension. Such 


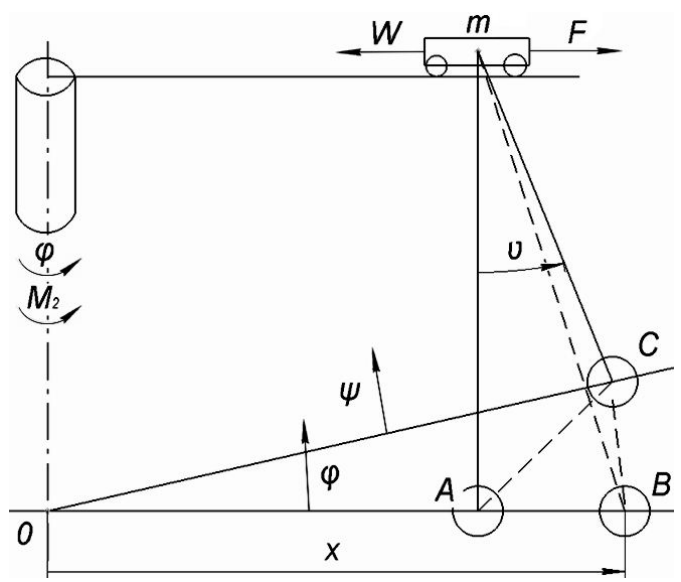

Fig. 1. Dynamic model of the slewing mechanism with steady state mode of the fly out change oscillations are complex in nature and occur in radial and tangential directions. In addition, they cause difficulty in load positioning. Their elimination is quite a difficult task, which experienced crane operators managed to cope with by constant monitoring of the mechanisms of tower crane's slew and change of load's fly out. In order to establish the main factors that influence

their appearance, it is necessary to synthesize mathematical models of the joint masses motion of the tower cranes mechanisms.

In $[7,8]$, a mathematical model of a crane's boom(jib) system with two degrees of freeness was developed. The authors examined the uniformly and non-uniforly accelerated tilt of the guide link (crane's boom). Nonlinear models have also been used to study oscillations on a flexible suspension [9].

In [10], the dynamics of a tower crane under the condition of pendular load oscillations (they are modeled as linear) was investigated. The construction of the tower crane is described with the finite element method. Dynamic load analysis was performed using an author-developed approach based on numerical method. It is established that the crane metal structure is most responsive to the influences which have the frequencies of the first several harmonics of metal structure oscillations and load oscillations as well. In addition, dynamic loads tend to increase as the angle of pendulum (load) deflection increases too.

In [11], a crane rotation simulation was performed based on the EulerLagrange equations. The analysis of the obtained results made it possible to trace the nature of the pendulum oscillations of the load on a flexible suspension and to compare them with the results of experimental studies. To minimize the load oscillatons, authors have come up with a method for controlling the driving torque of the crane slewing mechanism.

In the dissertation work [12] the influence of pendulum load oscillations on mechanical stresses of crane metal structure for different modes of its motion is investigated. On the basis of the analysis the author made a recommendation as to the position of the trolley on the boom in the condition of wind gusts for reducing the risk of emergency crane collapse. 


\section{Purpose and research task statement}

The purpose of the work is to establish the level of dynamic and energy load of the tower crane slewing mechanism, as well as to study the load oscillations on a flexible suspension. To achieve this goal it is necessary to solve the following problems: 1) to develop a dynamic model of the tower crane slewing mechanism; 2) to synthesize a mathematical model, which is suitable for research, by using a second-order Lagrange equation; 3 ) to analyze the dynamic and energy load of the tower crane slewing mechanism; 4) to investigate the appearence and evolution of the load oscillations on a flexible suspension and to determine the main factors that affect it.

\section{Research results}

The tower crane in the process of starting-up the slewing mechanism in steady-state mode of fly out change will be presented as a holonomic mechanical system (Fig. 1), which consists of absolutely rigid bodies, except for load flexible suspension, which oscillates in the vertical plane of fly out change and when crane is slewing. In the selected dynamic model of the crane we have generalized coordinates, accepted angular coordinates of the crane slew $\varphi$ and the load $\psi$, as well as the linear coordinate of the load movement thoughout the plane of fly out change $x$.

For such a dynamic model, we define the deviation of the load rope from the vertical. In this case, we assume that the deviation of the rope from the vertical, as in the plane of fly out chang, as the crane slew is negligible and does not exceed $12^{\circ}$. Therefore, the arc load movement during its oscillations is replaced by straight lines. As a result we will have next:

$$
\begin{gathered}
A B=x-v t, \\
B C=x(\varphi-\psi), \\
A C=\sqrt{A B^{2}+B C^{2}-2 A B \cdot B C \cdot \cos \angle A B C},
\end{gathered}
$$

where $t$ is time; $v$ - steady linear speed of the trolley movement.

For expression (3) we will find $\angle A B C$ :

$$
\angle A B C=\frac{\pi-(\psi-\varphi)}{2}=\frac{\pi}{2}-\frac{\psi-\varphi}{2} .
$$

As a result of substituting dependencies (1), (2) and (4) into expression (3) we will obtain:

$$
\begin{aligned}
A C & =\sqrt{(x-v t)^{2}+x^{2}(\psi-\varphi)^{2}-2 x(x-v t)(\psi-\varphi) \cos \left(\frac{\pi}{2}-\frac{\psi-\varphi}{2}\right)}= \\
& =\sqrt{(x-v t)^{2}+x^{2}(\psi-\varphi)^{2}-2 x(x-v t)(\psi-\varphi) \sin \left(\frac{\psi-\varphi}{2}\right)} .
\end{aligned}
$$

Then the angular coordinate of the deviation of the load rope from the vertical is determined by the dependence:

$$
v=\frac{A C}{L}=\frac{\sqrt{(x-v t)^{2}+x^{2}(\psi-\varphi)^{2}-2 x(x-v t)(\psi-\varphi) \sin \left(\frac{\psi-\varphi}{2}\right)}}{L} .
$$


The motion level of the crane's boom system is represented by the dynamic model shown in Fig. 1, we construct on the basis of the Lagrange equations of the second order:

$$
\left\{\begin{array}{l}
\frac{d}{d t} \frac{\partial T}{\partial \dot{\varphi}}-\frac{\partial T}{\partial \varphi}=Q_{\varphi}-\frac{\partial \Pi}{\partial \varphi} \\
\frac{d}{d t} \frac{\partial T}{\partial \dot{\psi}}-\frac{\partial T}{\partial \psi}=-\frac{\partial \Pi}{\partial \psi} \\
\frac{d}{d t} \frac{\partial T}{\partial \dot{x}}-\frac{\partial T}{\partial x}=-\frac{\partial \Pi}{\partial x}
\end{array}\right.
$$

where $T, \Pi$ is the kinetic and potential energy of the boom system, respectively; $Q \varphi$ is a non-potential component of the generalized force that corresponds to the generalized coordinate $\varphi$ of the crane's slew.

The potential energy of the boom system looks like:

$$
\Pi=m_{1} g L+m g L(1-\cos v) \text {, }
$$

where $m_{1}, m$ - respectively the weight of the trolley and the load; $g$ acceleration of free fall. Taking partial derivatives of expression (7) with respect to the dependence (5) of the generalized coordinates $\varphi, \psi$ and $x$, we have:

$$
\begin{gathered}
\frac{\partial \Pi}{\partial \varphi}=-\frac{m g}{L} x v t(x-\varphi), \\
\frac{\partial \Pi}{\partial \psi}=\frac{m g}{L} x v t(x-\varphi), \\
\frac{\partial \Pi}{\partial \psi}=\frac{m g}{L}\left(x-v t\left(1-\frac{(x-\varphi)^{2}}{2}\right)\right) .
\end{gathered}
$$

The kinetic energy of the boom system is expressed by next dependency:

$$
T=2 \frac{I_{1}}{D^{2}} v^{2}+\frac{1}{2} m_{1} v^{2}\left(1+\dot{\varphi}^{2} t^{2}\right)+\frac{1}{2} I_{2} \dot{\varphi}^{2}+\frac{1}{2} m\left(\dot{x}^{2}+x^{2} \dot{x} \dot{\psi}^{2}\right) .
$$

Taking the necessary systems (6) derivatives from the expression (11), we obtain:

$$
\begin{gathered}
\frac{\partial T}{\partial \varphi}=0, \quad \frac{\partial T}{\partial \psi}=0, \quad \frac{\partial T}{\partial x}=m x \dot{\psi}^{2}, \\
\frac{\partial T}{\partial \dot{\varphi}}=m_{1} v^{2} \dot{\varphi}^{2} t+I_{2} \dot{\varphi}=\left(m_{1} v^{2} \dot{\varphi} t+I_{2}\right) \dot{\varphi}, \\
\frac{\partial T}{\partial \dot{\psi}}=m x^{2} \dot{\psi}, \\
\frac{\partial T}{\partial \dot{x}}=m \dot{x}, \\
\frac{d}{d t} \frac{\partial T}{\partial \dot{\varphi}}=\left(m_{1} v^{2} t+I_{2}\right) \ddot{\varphi}+2 m_{1} v^{2} t \dot{\varphi},
\end{gathered}
$$




$$
\begin{gathered}
\frac{d}{d t} \frac{\partial T}{\partial \dot{\psi}}=m x^{2} \ddot{\psi}+2 m x \dot{x} \dot{\psi}, \\
\frac{d}{d t} \frac{\partial T}{\partial \dot{x}}=m \ddot{x} .
\end{gathered}
$$

The nonpotential component of the generalized force which corresponds to the generalized coordinate $\varphi$ is determined by the following dependency:

$$
Q_{\varphi}=\frac{2 M_{c r} u \eta\left(1+a s_{c r}\right)}{\frac{s_{c r}}{1-\left(\dot{\varphi} u / \omega_{0}\right)}+\frac{1-\left(\dot{\varphi} u / \omega_{0}\right)}{s_{c r}}+2 a s_{c r}}-M_{0},
$$

where $M_{c r}$ maximum (critical) moment on the electromotor's shaft of the crane slewing mechanism; $u$ and $\eta$ are respectively the gear ratio and the efficiency coefficient of the crane slewing mechanism; $\omega_{0}$ synchronous angular velocity of the rotor of the electromotor of the crane slewing mechanism; $s_{c r}$ critical slippage of the engine of the slewing mechanism, which is determined by the following dependency:

$$
s_{c r}=\left(1-\frac{\omega_{\text {nom }}}{\omega_{0}}\right)\left(\lambda+\sqrt{\lambda^{2}-1}\right),
$$

where $a=R_{1} / R_{2}^{\prime}$ dimensionless parameter, which is the ratio of the resistance of the stator $R_{1}$ to the resistance of the rotor $R_{2}{ }^{\prime}$, reduced to the stator windings; $\omega_{\text {nom }}$ the nominal angular velocity of the motor rotor; $\lambda=M_{c r} / M_{\text {nom }}$ is a torque capacity; $M_{\text {nom }}$ the nominal moment on the motor shaft.

After substitution of expressions (8)-(19) to a system (6) we obtain a system of differential equations of start-up of the crane slewing mechanism at the steady state mode of the load trolley motion:

$$
\left\{\begin{array}{l}
\left(I_{2}+m_{1} v^{2} t^{2}\right) \ddot{\varphi}+2 m_{1} v^{2} t \dot{\varphi}=\frac{2 M_{c r} u \eta\left(1+a s_{c r}\right)}{s_{c r}\left(1-\frac{\dot{\varphi} u}{\omega_{0}}\right)^{-1}+\left(1-\frac{\dot{\varphi} u}{\omega_{0}}\right) s_{c r}^{-1}+2 a s_{c r}}-M_{0}+\frac{m g}{L} x v t(\psi-\varphi) ; \\
m x^{2} \ddot{\psi}+2 m x \dot{x} \dot{\psi}=\frac{m g}{L} x v t(\psi-\varphi) ; \\
m \ddot{x}+m x \ddot{\psi}^{2}=-\frac{m g}{L}\left(x-v t\left(1-\frac{(\psi-\varphi)}{2}\right)\right) .
\end{array}\right.
$$

In the following presentation with the model (21), the results of the process of starting-up the tower crane slewing mechanism with the steady state mode of movement of the load trolley were analyzed.

All calculations were made for the parameters of the crane Liebherr $140 \mathrm{hc}$ [13], which are shown in the Table 1. 
Table 1

Calculated parameters of the tower crane Liebherr $140 \mathrm{hc}$

\begin{tabular}{|l|c|c|}
\hline \multicolumn{1}{|c|}{ Parameter } & $\begin{array}{c}\text { Unit of } \\
\text { measurement }\end{array}$ & Value \\
\hline Trolley weight, $m_{1}$ & $\mathrm{~kg}$ & 300 \\
\hline Load weight, $m$ & $\mathrm{~kg}$ & 5000 \\
\hline $\begin{array}{l}\text { The moment of inertia of the turnable part of the } \\
\text { crane relative to its own slewing axis, } I_{0}\end{array}$ & $\mathrm{~kg} \cdot \mathrm{m}^{2}$ & $5,5 \cdot 10^{6}$ \\
\hline $\begin{array}{l}\text { The moment of inertia of the rotor of the } \\
\text { electromotor of the load fly out change mechanism, } \\
I_{1}\end{array}$ & $\mathrm{~kg} \cdot \mathrm{m}^{2}$ & 0,3 \\
\hline $\begin{array}{l}\text { The moment of inertia of the rotor of the } \\
\text { electromotor of the crane slewing mechanism, } I_{2}\end{array}$ & $\mathrm{~kg} \cdot \mathrm{m}^{2}$ & 0,056 \\
\hline $\begin{array}{l}\text { The force of static resistance of the trolley } \\
\text { movement, } W\end{array}$ & $\mathrm{~N}$ & 5500 \\
\hline $\begin{array}{l}\text { The moment of static resistance of the crane slew, } \\
M_{0}\end{array}$ & $\mathrm{Nm}$ & 50100 \\
\hline $\begin{array}{l}\text { The maximum torque on the electromotor shaft of } \\
\text { the drive mechanism slewing crane, } M_{c r}\end{array}$ & $\mathrm{Nm}$ & 120 \\
\hline $\begin{array}{l}\text { The dimensionless parameters of the electromotor } \\
\text { of the driving mechanism slewing crane, } a_{1}\end{array}$ & - & 0,2 \\
\hline $\begin{array}{l}\text { The dimensionless parameters of the electromotor } \\
\text { of the driving mechanism slewing crane, } a_{2}\end{array}$ & - & 0,2 \\
\hline $\begin{array}{l}\text { Critical slippage of the engine of the crane slewing } \\
\text { mechanism } \boldsymbol{s}_{c r} 2\end{array}$ & - & 0,37 \\
\hline $\begin{array}{l}\text { The gear ratio drive mechanism of the crane slew, } \\
U_{2}\end{array}$ & - & 1429 \\
\hline $\begin{array}{l}\text { The synchronous angular velocity of the engine } \\
\text { shaft of the slewing crane mechanism, } \omega_{0}\end{array}$ & $\mathrm{rad}$ & 104,7 \\
\hline $\begin{array}{l}\text { The drum diameter of the slewing crane } \\
\text { mechanism of the trolley movement, } D\end{array}$ & $\mathrm{~m}$ & 0,3 \\
\hline The length of the load's flexible suspension, $L$ & - & 10 \\
\hline $\begin{array}{l}\text { Efficiency coefficient of the drive mechanism of } \\
\text { the crane slew, } \eta_{2}\end{array}$ & $\mathrm{~m}$ \\
\hline
\end{tabular}

In order to analyze the tower crane slewing mode with the constant velocity of the load trolley motion we have to build following graphical dependencies (Fig. 2). 


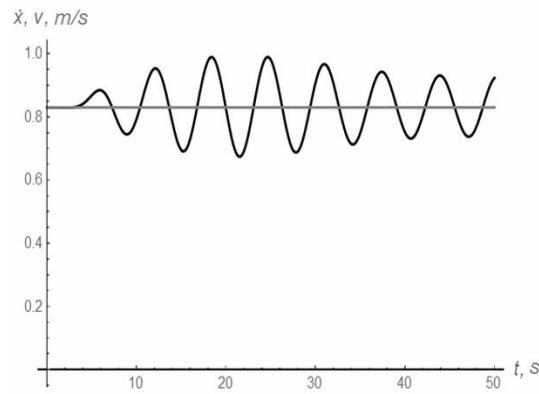

(a)

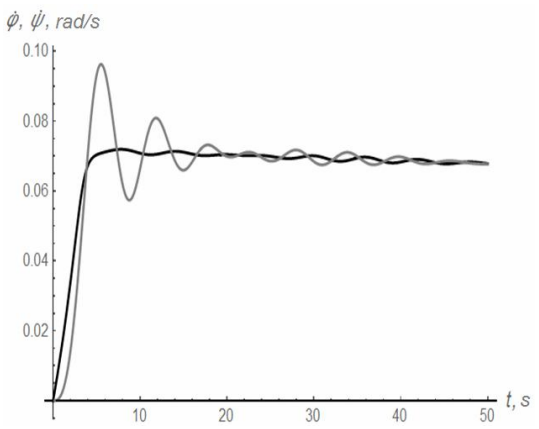

(c)

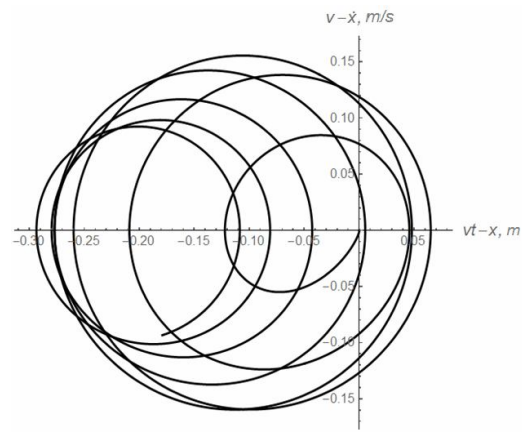

(e)

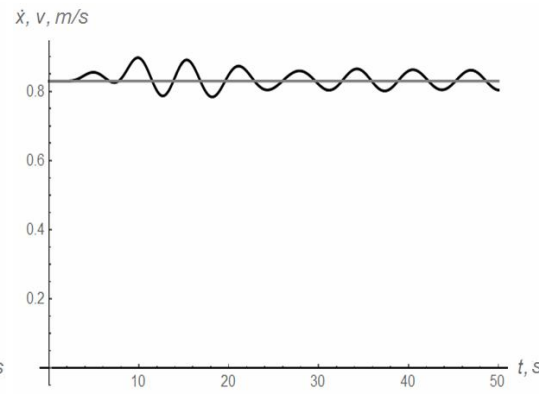

(b)

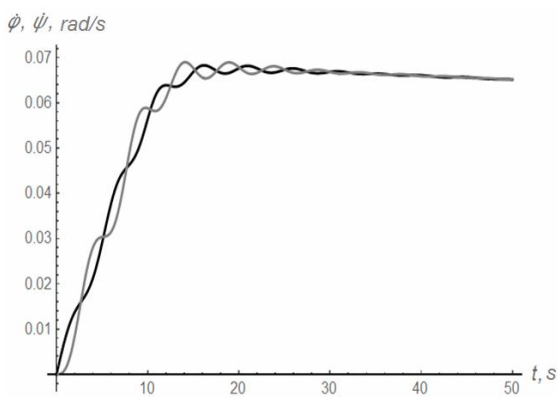

(d)

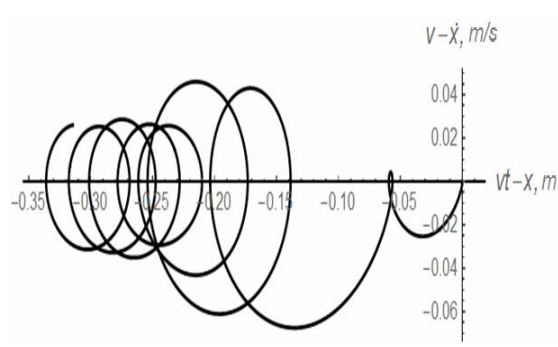

(f)

Fig. 2. Graphical dependencies of the crane start-up mode characteristics:

(a) velocity of the trolley (grey line) and the load (black line) in the radial direction at $x_{0}=3 \mathrm{~m}$;

(b) the same at $x_{0}=30 \mathrm{~m}$;

c) angular velocity of the tower (black line) and the load (grey line) in the tangential direction $x_{0}=3 \mathrm{~m}$;

d) the same $x_{0}=30 \mathrm{~m}$;

e) the phase portrait of radial load oscillations at $x_{0}=3 \mathrm{~m}$;

f) the same at $x_{0}=30 \mathrm{~m}$; 


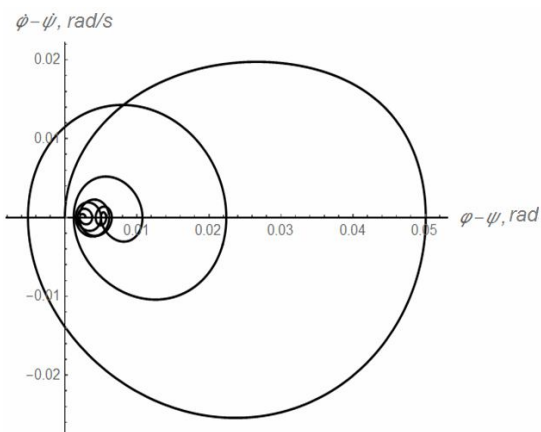

(g)

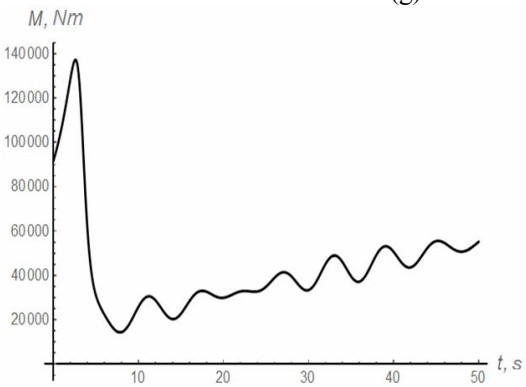

(i)

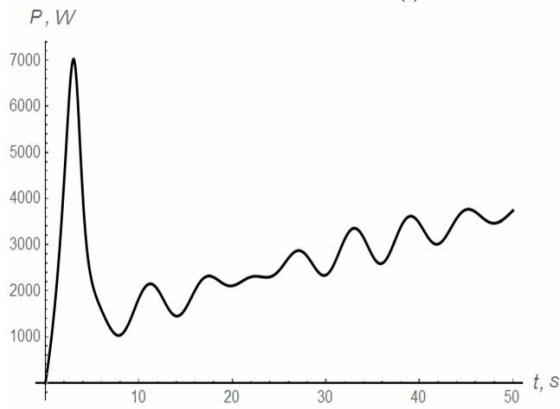

(k)

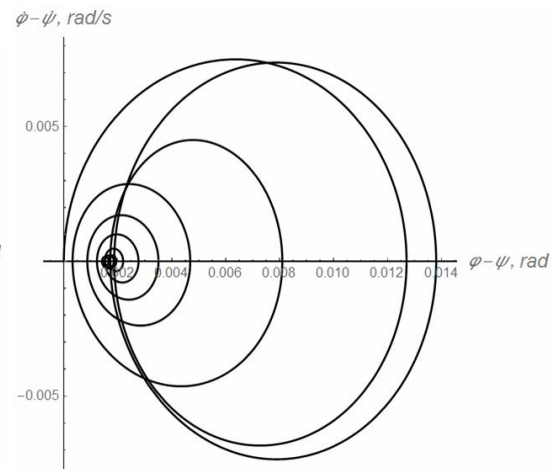

(h)

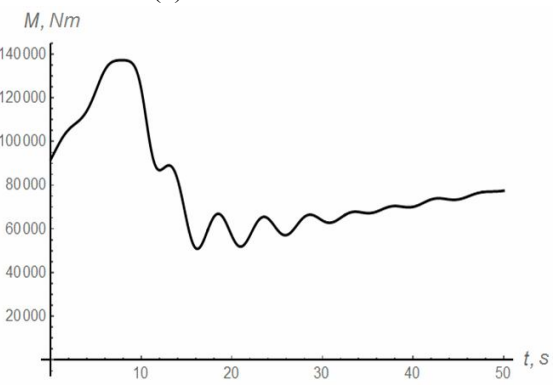

(j)

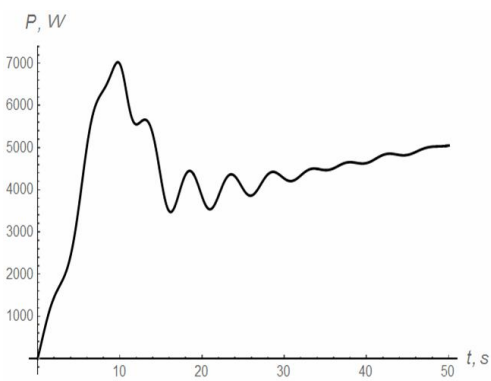

(1)

Fig. 2 (continuation). Graphical dependencies of the crane start-up mode characteristics: g) the phase portrait of the load oscillations in the tangential direction at $x_{0}=3 \mathrm{~m}$;

h) the same at $x_{0}=30 \mathrm{~m}$;

i) the driving torgue of the drive mechanism of the tower at $x_{0}=3 \mathrm{~m} ; \mathrm{j}$ ) the same at $x_{0}=30 \mathrm{~m}$;

k) the drive power of the crane slewing mechanism at $x_{0}=3 \mathrm{~m}$;

1) the same at $x_{0}=30 \mathrm{~m}$

Graphical dependencies in Fig. 2 we show as follows: in the left column the graphs correspond to the case $x_{0}=3 \mathrm{~m}$, and in the right - case $x_{0}=30 \mathrm{~m}$.

To establish the quantitative characteristics of the movement of the system, the numerical data that were entered in the Table 2, were calculated. 
Table 2

Kinematic, power and energy characteristics of start-up of the tower crane mechanism

\begin{tabular}{|l|c|c|c|}
\hline \multicolumn{1}{|c|}{ Parameter } & \multirow{2}{*}{$\begin{array}{c}\text { Unit of } \\
\text { measurement }\end{array}$} & \multicolumn{2}{|c|}{ Value at $x_{0}$} \\
\cline { 3 - 4 } & $\mathrm{Nm}$ & \multicolumn{2}{|c|}{137253} \\
\hline $\begin{array}{l}\text { Maximum torque value of the drive of } \\
\text { the crane's slew }\end{array}$ & $\mathrm{W}$ & \multicolumn{2}{|c|}{6993} \\
\hline $\begin{array}{l}\text { The maximum value of the drive power } \\
\text { of the crane's slew }\end{array}$ & $\mathrm{m}$ & 0,294 & 0,336 \\
\hline $\begin{array}{l}\text { The maximum amplitude of the load } \\
\text { deviation in the radial direction }\end{array}$ & $\mathrm{rad}$ & 0,0501 & 0,0138 \\
\hline $\begin{array}{l}\text { Maximum amplitude of load deviation in } \\
\text { tangential direction }\end{array}$ & $\mathrm{Nm}$ & 112213 & 111001 \\
\hline $\begin{array}{l}\text { The root-mean-square value of the drive } \\
\text { torque of the crane's slew }\end{array}$ & $\mathrm{W}$ & 4456 & 4837 \\
\hline $\begin{array}{l}\text { The root-mean-square drive power value } \\
\text { of the crane's slew }\end{array}$ & $\mathrm{m}$ & 0,00093 & 0,10744 \\
\hline $\begin{array}{l}\text { The root-mean-square deviation value of } \\
\text { the load in the radial direction }\end{array}$ & $\mathrm{rad}$ & 0,0306 & 0,0076 \\
\hline $\begin{array}{l}\text { The root-mean-square deviation value of } \\
\text { the load in the tangetial direction }\end{array}$ & & & \\
\hline
\end{tabular}

Analysis of the graphical dependencies, which are presented in Fig. 2, and the numerical data entered in the Table 2, shows that the maximum torque and power values for the cases $x_{0}=3 \mathrm{~m}$ and $x_{0}=30 \mathrm{~m}$ are the same. This derives from the overload capability of the crane slewing mechanism. In addition, practically equal root-mean-squere values of these characteristics can be observed.

For the case $x_{0}=30 \mathrm{~m}$, as we can see from Fig. 2 (j) and Fig. 2 (1), the torque and power of the mechanism's slew after the end of transient mode are higher. Thus, the magnitude of the initial load fly out causes the increase of these characteristics. This is due to the fact that with increasing the distance of the trolley relative to the rotational axis, firstly, the moment of system inertia increases, and secondly the angular speed of the crane's slew decreases. To compensate the speed reduction, it is necessary to provide the system with angular acceleration. The product of this acceleration at the increasing moment of inertia caused by the increase in the distance from the trolley to the axis of the crane's slew, causes an increase (compensating) of the engine driving torque. Moreover, the torgue increase causes a slight decrease in the angular speed of the crane's slew (Fig. 2 (c) and (d)).

Inspite of this, a larger value of $x_{0}$ causes an increase in the amplitude of the pendulum oscillations of the load in the radial direction. Here, the reason for such an increase is the centrifugal force, which will be as much as value of $x_{0}$. Indeed, as can be seen from Fig. 2 (f), the load over the time deviates more radially from the vertical due to the centrifugal force. 
On the other hand, the amplitude of the load oscillations in the tangential direction is smaller, which is obviously the reason that, in the case of $x_{0}=30 \mathrm{~m}$, the crane mechanism's starting time is much longer (again, this is caused by an increased moment of the system inertia at a larger value of $x_{0}$ ). Similar tendencies are observed when analyzing the root-mean-square values of the load oscillations in both planes.

\section{Conclusions}

1. A dynamic model and an adequate mathematical model for the movement of the crane slewing mechanism with a constant velocity of the trolley movement have been developed. The torgue (force) of the drive is modeled using the Kloss equation.

2. A complex of kinematic, power and energy parameters were proposed, which made it possible to characterize the movement of the cranes lewing mechanism. These metrics reflect maximum and root-mean-square values.

3. The analysis of the modes of joint movement of mechanisms is carried out and it is established that the drive of the mechanism's slew during the transitional mode of movement is overloaded by torque and power. The set power value of the crane slewing mechanism is proportional to the distance from the trolley to the rotational axis. This is the same what refers to the drive torgue.

4. The maximum value of the total power of the mechanisms of the load fly out change and the crane's slew at different $x_{0}$ is approximately the same, although the moment of occurrence of the maximum depends on the value $x_{0}$.

5. The basic regularities of the load oscillations appearance in the radial and tangential directions, which are in the subsidence of oscillations, which are related to the damping ability of gears, the action of centrifugal force and Coriolis force.

\section{REFERENCES}

1. Vaynson A.A. Pod'emno-transportnye mashiny (Lifting and transporting machines)/ A.A. Vaynson. - M. Mashinostroenie, 1989.-536 s.

2. Gaydamaka V.F. Gruzopod'emnye mashiny (Hoisting machines)/ V.F. Gaydamaka. - K.: Vishcha shkola, 1989. - 328s.

3. Gruzopod'emnye krany (Hoisting cranes). Kn. 2 / Sheffler M., Dresig Kh., Kurt F.; [transl. s nemeczkogo M.M. Runov, V.N. Fedoseev]; pod red. M.P. Aleksandrova. - M.: Mashinostoenie, 1981. - $287 \mathrm{~s}$.

4. Gohberg M.M. Metallicheskie konstrukczii pod'emno-transportnykh mashin (Metal structures of hoisting-and-transport machines) / M.M. Gohberg. - M.: Mashinostroenie, 1969. $-520 \mathrm{~s}$.

5. Kazak S.A. Dinamika mostovykh kranov (Dynamics of overhead cranes) / S.A. Kazak. - M.: Mashinostroenie, 1968. - $331 \mathrm{~s}$.

6. Lobov N.A. Dinamika gruzopod'emny 'kh kranov (The dynamics of cranes) / N.A. Lobov. M.: Mashinostroenie, 1987. $-160 \mathrm{~s}$.

7. Priymakov O.G. Matematichna model` kolivan` vantazhu pri povoroti krana pi`djomnotransportnoyi mashini (Mathematical model of load oscillations when turning the crane of a hoisting machine) / O. G. Priymakov, Yu. O. Gradis'kii // Sil's'kogospodars'ki mashini. 2013. - Vip. 25. - S. 111-117.

8. Kuz min A.N. Issledovanie kolebanij gruza na gibkom podvese pri povorote krana (Investigation of vibrations of a load on a flexible suspension when turning a crane) / A.N. 
Kuz`min, V.V. Suglobov, V.I. Fedun // Zakhist metalurgi'jnikh mashin vid polomok: zbirnik naukovikh pracz' / PDTU. - Mariupol', 2011. - Vip. 13. - S. 141-147.

9. Loveykin V.S. Nelinijni mayatnikovi kolivannya vantazhu na gnuchkomu pidvsi pri riznikh rezhimakh obertannya (Nonlinear pendulum oscillations of the load on a flexible suspension at different modes of rotation) / V.S. Loveykin, A.V. Boyko, Yu.V. Chovnyuk // Visnik TNTU. - 2010. - Tom 15. - \# 3. - S. 41-48.

10. Bulatov Zh.L. Sostoyanie voprosa dinamiki bashennykh kranov $\mathrm{s}$ uchetom bol'shikh peremeshhenij (The state of the art of tower cranes dynamics, taking into account large movements) / Zh.L. Bulatov, A.V. Sinel'shhikov // Vestnik Astrakhanskogo gosudarstvennogo tekhnicheskogo universiteta. - 2014. - \#1 (57). - S. 23-29.

11. Hamid Nalbandian Abhar. Dynamic Analysis of the Tower Crane / Dissertation submitted to the faculty of engineering, university of malaya in partial fulfillment of the requirement for the degree of master of mechanical engineering. - P 125.

12. Tower crane Liebherr $140 \mathrm{HC} / \mathrm{URL}$ : https://cranemarket.com/specs/liebherr/140-hc (data zvernennya 07.02.2020).

Стаття надійшла 15.08.2020

Ловейкін В.С., Ромасевич Ю.О., Курка В.П., Муштин Д.І., Почка К.І.

АНАЛІЗ ПРОЦЕСУ ПУСКУ МЕХАНІЗМУ ПОВОРОТУ БАШТОВОГО КРАНА ПРИ УСТАЛЕНОМУ РЕЖИМІ РУХУ ВАНТАЖНОГО ВІЗКА

Розроблено динамічну модель процесу повороту баштового крана з балочною стрілою при умові, що вантажний візок виконує рух із усталеною швидкістю. На основі рівнянь Лагранжа другого роду отримано відповідну математичну модель, яка, крім того, описує коливання вантажу на гнучкому підвісі у тангенціальному та радіальному напрямках. Рушійний момент, прикладений до системи, змодельовано за допомогою рівняння Клосса. Отримана математична модель представляється системою чотирьох нелінійних диференціальних рівнянь другого порядку, тому для ії інтегрування використано чисельні методи. Для оцінки рівня динамічних та енергетичних навантажень у елементах системи запропоновано комплекс показників, які відображають максимальні та середньоквадратичні величини. Запропоновано розглядати еволюцію системи для двох випадків: положення візка біля башти (візок рухається від неї) та положення візка біля кінця стріли (візок рухається до башти). Для обох випадків було розраховано значення оціночних показників, які разом із відповідними графічними залежностями дозволили виявити найбільш значимі фактори, що мають вплив на енергетичні, динамічні на кінематичні процеси системи. До них, зокрема, належать: відцентрова сила, сила Коріоліса, демпфуюча здатність асинхронного електроприводу механізму повороту крана. Аналіз коливань вантажу на гнучкому підвісі, який проведений на основі фазових портретів у площині руху візка та перпендикулярно їй, виявив їх залежність від початкового положення візка на стрілі. Крім того, від цього фактора значно залежать споживана потужність приводу, частина якої витрачається на подолання відцентрової сили, що діє на візок і вантаж.

Ключові слова: математична модель, поворот, баштовий кран, коливання вантажу, аналіз, рівняння Лагранжа.

Loveikin V.S., Romasevych Yu.O., Kurka V.P., Mushtyn D.I., Pochka K.I.

ANALYSIS OF THE START-UP PROCESS OF THE TOWER CRANE SLEWING MECHANISM WITH A STEADY STATE MOTION MODE OF ITS LOAD TROLLEY

A dynamic model of the process of a tower crane slew with a saddle jib has been developed, provided that the load trolley moves at a constant velocity. On the basis of the second-order Lagrange equations, a corresponding mathematical model is obtained, which also describes the oscillations of the load on a flexible suspension in tangential and radial directions. The driving torque applied to the system is modeled using the Kloss equation. The obtained mathematical model is represented by a system of four second-order nonlinear differential equations, so numerical methods are used to integrate it. To assess the level of dynamic and energy loads in the system elements, we propose a set of indicators that reflect the maximum and root-mean-square values. It is suggested to consider the evolution of the system in two cases: the position of the 
trolley near the tower (the trolley moves from it) and the position of the trolley near the end of the boom (the trolley moves towards the tower). For both cases, the values of the estimation parameters were calculated, which together with the corresponding graphical dependencies allowed to identify the most significant factors that have an impact on the energetic, dynamic and kinematic processes of the system. In particular, these include: centrifugal force, Coriolis force, damping ability of the asynchronous electric drive of the crane slewing mechanism. The analysis of the load oscillation on a flexible suspension, which was carried out on the basis of phase portraits in the plane of the trolley movement and perpendicular to it, revealed their dependence on the initial position of the trolley on the boom. Apart from this, the drive power consumption, a part of which is spent on overcoming the centrifugal force which acts on the trolley and the load, significantly depends on this factor.

Keywords: mathematical model, slewing, tower crane, load oscillations, analysis, Lagrange equations.

\section{Ловейкин В.С., Ромасевич Ю.А., Курка В.П., Муштын Д.И., Почка К.И.}

\section{АНАЛИЗ ПРОЦЕССА ПУСКА МЕХАНИЗМА ПОВОРОТА БАШЕННОГО КРАНА ПРИ УСТАНОВИВШЕМСЯ РЕЖИМЕ ДВИЖЕНИЯ ГРУЗОВОЙ ТЕЛЕЖКИ}

Разработана динамическая модель процесса поворота башенного крана с балочной стрелой при условии, что грузовая тележка выполняет движение с установившейся скоростью. На основании уравнений Лагранжа второго рода получена соответствующая математическая модель, которая, кроме того, описывает колебания груза на гибком подвесе в тангенциальном и радиальном направлениях. Движущий момент, приложенный к системе, смоделирован с помощью уравнения Клосса. Полученная математическая модель представляется системой четырех нелинейных дифференциальных уравнений второго порядка, поэтому для ее интегрирования использованы численные методы. Для оценки уровня динамических и энергетических нагрузок в элементах системы предложен комплекс показателей, отражающих максимальные и среднеквадратичные величины. Предложено рассматривать эволюцию системы для двух случаев: положение тележки у башни (тележка движется от нее) и положение тележки у конца стрелы (тележка движется к башне). Для обоих случаев было рассчитано значение оценочных показателей, которые вместе с соответствующими графическими зависимостями позволили выявить наиболее значимые факторы, влияющие на энергетические, динамические на кинематические процессы системы. К ним, в частности, относятся: центробежная сила, сила Кориолиса, демпфирующая способность асинхронного электропривода механизма поворота крана. Анализ колебаний груза на гибком подвесе, который проведен на основе фазовых портретов в плоскости движения тележки и перпендикулярно ей, обнаружил их зависимость от начального положения тележки на стреле. Кроме того, от этого фактора значительно зависит потребляемая мощность привода, часть которой расходуется на преодоление центробежной силы, действующей на тележку и груз.

Ключевые слова: математическая модель, изменение вылета, совмещение движений, манипулятор, уравнение Лагранжа второго рода, динамические нагрузки, колебания груза.

\section{УДК 621.87}

Ловейкін В.С., Ромасевич Ю.О., Курка В.П., Муштин Д.І., Почка К.І.

Аналіз процесу пуску механізму повороту баштового крана при усталеному режимі руху вантажного візка // Опір матеріалів і теорія споруд: наук.-тех. збірн. - К.: КНУБА, 2020. - Вип. 105. - С. 232-246.

Розроблено математичну модель повороту баштового крана при умові постійної швидкості руху візка по стрілі. Модель, яка отримана на основі рівнянь Лагранжа другого роду, враховуе тангенціальні та радіальні коливання вантажу на гнучкому підвісі. Проведено аналіз руху системи при умові переміщення візка до башти та від неї. Запропоновано комплекс оціночних показників, які дали змогу встановити рівень динамічної та енергетичної навантаженості механізму повороту крана, а також проаналізувати еволючію коливань вантажу на гнучкому підвісі.

Іл. 2. Бібліогр. 13 назв. 


\section{UDC 621.87}

Loveikin V.S., Romasevych Yu.O., Kurka V.P. Mushtyn D.I., Pochka K.I.

Analysis of the start-up process of the tower crane slewing mechanism with a steady state motion mode of its load trolley// Strength of Materials and Theory of Structures: Scientific-andtechnical collected articles - Kyiv: KNUBA, 2020. - Issue 105. - P. 232-246.

A mathematical model of tower crane's slew under the condition of constant velocity of the trolley motion on a boom has been developed. The model, derived from the second-order Lagrange equations, takes into account the tangential and radial load oscillations on a flexible suspension. An analysis of the system motion with the conditions of the trolley movement to and from the tower. A set of estimation indicators, which made it possible to establish the level of dynamic and energy load of the crane slewing mechanism, as well as to analyze the evolution of the load oscillations on a flexible suspension has been proposed.

Fig. 2. Ref. 13.

\section{УДК 621.87}

Ловейкин В.С., Ромасевич Ю.А., Курка В.П., Муштын Д.И., Почка К.И.

Анализ процесса пуска механизма поворота башенного крана при установившемся режиме движения грузовой тележки // Сопротивление материалов и теория сооружений: науч.-техн. сборн. Вып. 105. - К.: КНУСА, 2020. - С. 232-246.

Разработана математическая модель поворота баменного крана при условии постоянной скорости движения тележки по стреле. Модель, полученная на основе уравнений Лагранжа второго рода, учитывает тангенциальные и радиальные колебания груза на гибком подвесе. Проведен анализ движения системы при условии перемещения тележки к башне и от нее. Предложенный комплекс оценочных показателей, позволил установить уровень динамической и энергетической нагруженности механизма поворота крана, а также проанализировать эволюиию колебаний груза на гибком подвесе.

Ил. 2. Библиогр. 13 назв.

Автор (вчена ступень, вчене звання, посада): доктор технічних наук, професор, завідувач кафедри конструювання машин і обладнання Національного університету біоресурсів $i$ природокористування Украӥни ЛОВЕЙКІН Вячеслав Сергійович

Адреса робоча: 03041, Україна, м. Київ, вул. Героїв Оборони, 12, навчальний корпус № 11, Національний університет біоресурсів $i$ природокористування Украӥни, кафедра конструювання машин і обладнання, ЛОВЕЙКІНУ Вячеславу Сергійовичу

Робочий тел.: +38(044) 527-87-34;

Мобільний тел.: +38(097) 349-14-53;

E-mail: lovvs@ukr.net

ORCID ID: https://orcid.org/0000-0003-4259-3900

Автор (вчена ступень, вчене звання, посада): доктор технічних наук, доцент, професор кафедри конструювання машин $і$ обладнання Національного університету біоресурсів $i$ природокористування Украӥни РОМАСЕВИЧ Юрій Олександрович

Адреса робоча: 03041, Україна, м. Київ, вул. Героїв Оборони, 12, навчальний корпус № 11, Національний університет біоресурсів $i$ природокористування Украӥни, кафедра конструювання машин і обладнання, РОМАСЕВИЧУ Юрію Олександровичу

Робочий тел.: +38(044) 527-87-34;

Мобільний тел.: +38(068) 102-31-64;

E-mail: romasevichyuriy@ukr.net

ORCID ID: https://orcid.org/0000-0001-5069-5929 
Автор (вчена ступень, вчене звання, посада): кандидат технічних наук, стариий викладач кафедри тракторів, автомобілів та біоенергосистем Національного університету біоресурсів і природокористування Украӥни КУРКА Віталій Петрович

Адреса робоча: 03041, Украӥна, м. Київ, вул. Героїв Оборони, 12, навчальний корпус № 11, Національний університет біоресурсів $i$ природокористування Украӥни, кафедра тракторів, автомобілів та біоенергосистем, КУРЦІ Віталію Петровичу

Робочий тел.: +38(044) 527-88-95;

Мобільний тел.: +38(097) 72-00-365;

E-mail: vitaliikurka@gmail.com

ORCID ID: https://orcid.org/0000-0003-1247-6770

Автор (вчена ступень, вчене звання, посада): аспірант кафедри конструювання машин $i$ обладнання Національного університету біоресурсів $i$ природокористування України МУШТИН Денис Іванович

Адреса робоча: 03041, Україна, м. Київ, вул. Героїв Оборони, 12, навчальний корпус № 11, Національний університет біоресурсів $i$ природокористування України, кафедра конструювання машин і обладнання, МУШТИНУ Денису Івановичу

Робочий тел.: +38(044) 527-87-34;

Мобільний тел.: +38(098) 716-76-85;

E-mail: denismushtyn@gmail.com

ORCID ID: https://orcid.org/0000-0003-2416-1565

Автор (вчена ступень, вчене звання, посада): доктор технічних наук, дочент, завідувач кафедри професійної освіти КНУБА ПОЧКА Костянтин Іванович

Адреса робоча: 03037, Украӥна, м. Київ, Повітрофлотський проспект 31, Київський національний університет будівництва і архітектури, кафедра професійної освіти, ПОЧЦІ Костянтину Івановичу

Робочий тел.: +38(044) 248-69-25;

Мобільний тел.: +38(097) 212-86-29;

E-mail: shanovniy@ukr.net

ORCID ID: https://orcid.org/0000-0002-0355-002X 